生剂使用に関する考察一抗生㓮感受性と腹腔内膿榢形 成，予後との関係について一

新潟大学医学部第一外科 ${ }^{11}$, 新潟県立新発田病院外科 23

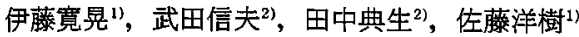

【目的】消化管手術の周術期感染症予防に抗生剤は重要 であると考えられる.腹膜炎術中採取腹水検出菌の抗生 風感受性が，腹腔内膿瘍形成と予後に関係するか検討し た.【方法】1985年から1998年までに手術を行った消化管 穿孔例(食道，虫垂を除く）で術中採取腹水細菌培養陽性 例を対象とした。術後3日目までの早期死亡例は除外し た，対象は160例，男性107例，女性53例，3-94歳，平均 年齢46.27歳であった.使用抗生剂が検出菌全てに抗菌力 を有する場合を complete match (CM)，検出菌の一部に 有する場合を partial match(PM),無効の場合を no match (NM) と定義した。（A)腹水検出菌と術当日抗生 剂, さらに術後3-6日目ドレーン培養陽性19症例に対し て (B) 㭘出菌と術後7日目抗生剤を調査した。統計には $\chi 2$ 検定を用い, 危険率5\%以下を有意とした。【結果】(A) CM109例, PM22例, NM29例, 術後1-6日目の腹整内膿 湟形成 $(p=0.850)$, 術後7日目以降の膿演形成 $(p=0$. 364), 予後 $(p=0.666)$, (B) CM13例, PM0例, NM6例, 術後7日目以降の膿瘍形成 $(\mathrm{p}=0.257)$, 予後 (死亡なし) のいずれにも有意差を認めなかった。【総括】抗生剤感受 性と, 腹腔内膿瘍形成, 予後に有意な関係を認めなかっ た。

\author{
0-639 下部消化管手術に掠ける手術部位感染予 \\ 防のための工夫 \\ 公立富岡総合病院外科 ${ }^{11}$, 群馬大学救急医学 ${ }^{21}$, 群馬大学 \\ 第二外科 ${ }^{3}$ \\ 高井良樹 ${ }^{1)}$ ，佐藤尚文 ${ }^{11}$ ，菊地麻美 ${ }^{1)}$ ，五十嵐清美 ${ }^{1)}$, \\ 清水 尚 ${ }^{1)}$, 横江隆夫 ${ }^{21}$, 飯野佑一 ${ }^{21}$, 森下靖雄 ${ }^{31}$
}

我々は患者の quality of life の向上および手術数増加に 伴う病床不足の解決を目的に入院期間の短縮に努めてい る. 高齢, 肥満, DM など感染の high risk 群が増加し ている現在, 手術部位感染予防は入院期間短縮という面 からも大きな課題である。準無菌手術である下部消化管 手術における感染予防対策を手術手技の工夫を中心に報 告する.【方法】手術前日は低残渣食とし, 当日朝に PEG のみで術前処置を行う，抗生剤は術中の高血中浱度を得 るため麻酔導入々同時に投与し，予防的投与は第2病日ま でとする。横切開で開腹し，腹壁創をウンドプロテクタ 一で保護. 結腸切除断端及び自動吻合器のアンビル装着 部はすぐに滅菌したビニール袋で被覆. 機械吻合直前に 腸管内をイソジン生食で洗浄。Miles 手術では口側腸管 断端をビニール袋で被覆したまま，腹膜外経路で体外に 引き出す。腹腔内洗浄後, 多項式ソフトドレーンを挿入. 皮膚縫合直前にブラシと生食で皮下組織を洗浄し，短い 皮下ドレーンを創端に挿入. 皮襡はステイプラーで閉創. イソジンガーグル含濑は入院から退院まで終始一貫して 指導.【結果】以上のような小さな工夫の積み重ねではあ るが，手術部位感染頻度は確笑に低下した。

\section{0-640 実験的腹膜炎の発症㙨棈について}

日本大学医学部第三外科11，日本大学医学部第三外科細 菌研究室 ${ }^{2}$

中山一誠1)，山地恵美子2)

〔目的〕近年教室で経験した积気性菌感染症81症例につ いて集計すると単独感染11例 $(13.6 \%)$ であり，他の70 例 $(86.4 \%)$ は混合感染である，その内容を詳細に検討 すると嫌気性菌，好気性菌による混合感染例てあること が判明した，そこでその病態生理を解明するるた，ラッ 卜腹膜炎モデルを作成した。〔方法〕Gelatin capsule 内 に菌液を挿入した B. fragilis，E．coli 各単独抽よび混 合感染の3群にて腹腔内酸化還元電位を測定し，更に ${ }^{14} \mathrm{C}-$ cefotetan 用い wholebody autoradiographyを作成 した.〔成績〕B. fragilis 単独群では死亡例はなく，E． colj 単独群では, 感染後1日以内に $38.5 \%$ が死亡した。一 方, E. coli・B. fragilis 群では2日以内に $80 \sim 100 \%$ 死 亡した，腹腔内酸化還元電位に関しては，生存群では平 均一 $300 \mathrm{mV}, \mathrm{E}$. coli 単独群では一 $500 \mathrm{mV}, \mathrm{E}, \mathrm{coli} ・ \mathrm{~B}$. fragilis 混合感染群ではー700mVであった。(結論]病態 生理は二相性感染機構であり，最終的には，菌血症，内 毒素血症，膿瘍形成および多臟器不全を示した。

\section{0-641 肝硬変併存手術症例における感染防御能 に関する検討 \\ 順天堂大学医学部第 2 外科 \\ 森岡研介, 藤澤 稔, 行方浩二, 高森 繁, 览島邦明, 樑澤正榑，別府倫兄，二川俊二}

【目的】非肝硬変症例と肝硬変症例における術前術後の 炎症反応の推移ならびに感染防御能の差異を比較検討す ることを目的とした。【方法】化学発光 (Chemiluminescence, 以下 CL)を用いた活性酸素放出能の変化を測定 することにより，血中の食細胞機能を定量的に解析する 事が可能である．肝硬変併存開腹手術例25例を対象とし て術前と術後の好中球数, 全血 CL 值 (Peak CL：活性酸 素放出能＝貪食能を反映, Peak Time：オプソニン活性 を反映), 各種生化学検査を測定し, 旰硬变症の有無によ る変動, 推移を比較検討した。【結果】 Peak Timeの推 移をみると, 肝硬変群において術後第 3 病日・第7病日で 高值 (延長) を示した $(p<0.05)$. 術前 Peak CL 值は, 所 硬変群は非硬変群と比較して低值の傾向を示した $(\mathrm{p}<$ 0.05).また，好中球1細胞あたりの貪食能を全血 $\mathrm{CL} /$ 好 中球数で換算したものでみると，術後第 3 病日以降で肝 硬変群で低值で推移する傾向を示した（第 3 病日 $\mathrm{p}=0$. 08 , 第7病日 $\mathrm{p}=0.07)$.【総括】肝硬変群では術後のオプ ソニン活性の低下を認め,同時に貪食細胞(本研究では好 中球)一つあたりの貪食能低下を認めた。これらは肝硬変 症の感染防御能低下の一因を示すものと考えられた。 


\section{$0-642$}

消化器外科周術期の肺合併症における感

染症対策

都立大塚病院外科1), 東京医科大学外科第一講座2)

與石晴也 ${ }^{12}$, 岡村 孝 ${ }^{11}$, 佐藤隆宣 ${ }^{12}$, 後藤博志 ${ }^{11}$,

蓮江健一郎"，三坂武温"，橋本大樹"，有馬正明"),

袷田安彦"1，水口博之"，石原通臣"，鳥屋城男 ${ }^{11}$,

加藤治文 ${ }^{21}$

【目的・方法】過去 3 年間に経験した消化器外科周術期 肺合併症併発 55 例について, その病態と気管支洗浄液 の細菌培養の検出菌を分析し，更にその治療について検 討した。【症例】部位別に食道 6 (悪性 5 良性 1 ), 胃 1 5 (德 12 良 3 ), 小腸 14 (徳 2 良 12 ), 大腸 11 (徳 8 良 3 ), 肝胆脺 9 (悪 5 良 4) 例.【結果】肺合併淀の 主病態《肺炎 28 , 無気肺 12 , 肺水腫 9, ARDS 4 , 胸水 2 例であった. 主たる検出菌は MRSA 15 , 緑賸菌 $6, \mathrm{M}+$ 緑 3 , 他の $\mathrm{G}(-)$ 桿菌 7 , 結核菌 2, その他 1 5 例であり，培養陰性は 7 例であった。治療は迅速な気 管支鏡による病巣の喀痰吸引・洗浄と, その培養検出菌 に対応した抗生剂投与, 病態に応じたステロイド投与, 更に気管笛刺針㨉入 $(21)$, 気管切開 $(8)$ を積極的に 行った. 予後は術死 5 例て肺炎死亡が 1 例 (M 1)，他病 死が 4 例（G(-)桿 2, 他菌 2) であった。【考萫】皘極 的な呼吸・全身管理と気管支洗浄液の細菌培堆結果の分 析が周術期の肺合併症における感染症対策として重要と 考えられた。

\section{$0-643$}

消化器外科手術後 MRSA 腸炎の実態と

リスクファクターの検討

名古屋第二赤十字病院外科

伊神 剛, 長谷川 洋, 小木曽清二, 塩見正哉,

料山正人, 太平周作, 森 俊治, 上原圭介, 服部弘太郎, 水野隆史，秋田昌利

【目的】消化器外科手術後の MRSA 腸炎は, 時に重篤と なり治療に難渋することがある。術後 MRSA 腸炎の夷 態とリスクファクターについて検討する。【対象と方法】 1997年4月から1999年7月までの全身麻酔による消化器外 科手術症例中, 術後MRSA 腸炎を発症した13例につい て, 術前抗生剂使用の有無, 術前消化管通過障害の有無, H2-blocker 使用の有無, を中心に検討した。【結果】1. 術前抗生剤使用の有無：4例(30.8\%)で,期間は2日, 3日, 25日，38日であった。2.術前消化管通過障害の有無：6例 (46.2\%)で，上部消化管 1 例，下部消化管5例であった。 3.H2-blocker 使用の有無：12例 $(92.3 \%)$ で, 術前術後7 例, 術前のみ2例, 術後のみ3例であった。尚, H2-blocker 未使用症例の1例は胃全摘出術症例であった。【考察】H2 -blocker 投与症例では，術後 MRSA 腸炎の発生に留意 すべきであると考えられた。術後 MRSA 腸炎の発生と， 衍前抗生剂使用および術前消化管通過障害との関連法明 かではなかった。

\section{O-644} 上下部消化管待機手術における抗菌薬投 与の基本方針

日鋼記念病院外科

高时誩二，勝木良雄，工藤岳秋，長谷川公治，藤森 聰， 岡田昌生, 浜田弘巴, 辻 寧重, 大平整爾

【目的】上下部消化管準梨菌待機手術において術後創感 染の頻度と適切な抗菌薬の使用基準について検討した。

【方法】胃癌待機手術 71 例（A 群：男 54 女 17 ) と 大腸直腸癌待機手術 63 例（B群：男 40 女 23 ）を対 象とした，A群には全例 CEZ $2 \sim 3$ 日間投与し B 群 に位 CEZ(16例)，CTM(39例)，FMOX(6例)，VCM(2 例)を $3 \sim 4$ 日間投与して, 術後創感染を評価した.【結 果】A 群は術後創感染は発症しなかったが，B 群では11 例 $(21 \%)$ に創感染を認めた。その内訳は CEZ(1例)， CTM (6 例), FMOX ( 3 例), VCM ( 1 例)であり, VCM の症例は術前より尿路感染があり術野外感染であった。 起炎菌は MRSA，Enterococcus spp が $25 \%$ で coli， $P$ aeruginosa が50\%, bacteroides が25\%であった.【総 括】A 群では目標とする細菌を絞り比較的抗菌スペクト ルが狭い薬剤を短期間投与することを基本方針としてき たが，今回の検討で抗菌剤投与の日数を短縮できる可能 性が示唆された，B 群では起炎菌の範囲が広いことと症 例自体が進行癌の場合など術前の病態の違いにより術中 の污染状態が多㞳にわたるため，症例に応じた抗生刜の 選択と投与時期及び投与量の検討が必要であると考えら れた。

O-645 大腸手術における感染予防を目的とした 抗生剂至適投与期間の検討

東海大学医学部外科

鈴木俊之，貞廣荘太郎，向山小百合，亀谷武彦，岩瀬弘 忠，石川健二，徳永信弘，石田秀樹，向井正哉，安田聖 栄, 田島知郎, 幕内博康

待機的な大腸手術においては，術前に腸管前処置を行い 術後には経静脈的に抗生剂が4〜7日間程度投与されてき たが、至適投与期間は確立していない.そこで周術期抗 生郕の至適投与期間を検討する目的で, 無作為割付試験 を行った。現在までに結腸手術症例59例，直腸手術症例 24例が登録された，前処置は，手術2日前にラキソベロン $10 \mathrm{ml}$ を内服し，前日午前中にニフレック $2,000 \mathrm{ml}$ を内 服，午後1時，2時，11時に各々カナマイシン0.5g，フラ ジール0.5g を内服した. 加刀1時間前より抗生剂を1時間 で点適し，手術時間が3時間を超えた場合には追加した。 結腸では FMOX1g, 直腸では CMZ1g を使用した. 結腸 では，FMOX1回のみの投与群(A 群)29例と手術当日加 ら術後3日間1日2回投与した群(B 群) 30例を比較した。 た直腸では, 術後3日間1日2回投与した群 (C 群) 12例と術 後6日閒投与した群 (D 群)を比較した。術後創感染は A 群4例, B 群 3 例, C 群1例, D 群 1 例に認められ, AB 群間, CD 群間の合併症の発生率に差を認めなかった。 
0-646 当院の外科入院患者に抢けるMR S A 感

染例の検討

興生総合病院

村上努士，漆畑貴行，山本吉浩，展瀨昌博，難波康男， 藤原恒弘

（目的）各種抗菌剤に耐性のあるMR S A の分離検体数 の增加しているが，当科でも術後の思者からの分離数が 増加しつつある. 我々はMR S A 検出状況の調查を行い, 患者背景因子・手術侵襲とMR S A 分離例との関連につ いて検討した。（方法)平成 7 年 1 月からの 5 年間のあい だに興生総合病院外科に入院した患者を対象 としてM R S A 分離例と非分離例それそれに年龄・性差・基礎疾 患・術前投与抗菌剤の有無・手術侵襲等について比較検 討を行った. (結果と考察) 調查を実施した 5 年間で術後 の患者でMRSAを分離した症例は 3 ないし $7 \%$ な゙っ た. 分離数が平成10年に増加し，平成11年には娍少した が, この間当院全体のMR S A 分離数は急増している。 この事は平成 11 年に術前・術後の抗菌剤の使用に指標を 設けた事が奏効したと考える。抗菌剤の使用期間が長く， 変更を行わなかった症例にMR S Aが多く検出された. 以上から手術部位に応じた抗菌刜の選択が必要で長期慎 むべきと思われる.さらに抗菌剤の使用に指標を設ける 事が有効であった。

\section{0-647}

消化管手術における周術期創感染対策の

工夫とその成果

千葉大学医学部第一外科

小田健司, 幸田圭史, 滝口伸浩, 鈴木弘文, 石井留魅子, 安冨 淳, 小林信義, 市川千秋, 里見大介, 飯塚 勇, 長谷川史郎, 土屋 博, 中島伸之

[目的］消化管手術に招ける創感染率，術中の細菌検出 率を調べ,諸工夫によりその改善を認めたので報告する。 [方法]（1）過去の創感染率：1998年10月から1999年2月 までの胃, 大腸手術における創感染率と検出細菌を調查. (2)創感染対策：1999年5月から2000年3月までの胃,大腸 手術において, 清潔操作の徹底, リングドレープの使用, 生理食塩水 $2-3000 \mathrm{ml}$ での腹腔内洗浄, 皮下洗浄, 抗生物 質の術中投与を行った。ささらに吻合用器具を介する contaminationを防ぐ吻合用プレートを試作した。忠た腹腔 洗浄液の一部を細菌学的検查に提出した. [成續, 結論] (1) 過去の創感染率：胃手術0/15 $(0 \%)$, 大腸手術 4 / $23(17.4 \%)$ ，計 $4 / 38(10.5 \%)$ の創感染率.（2）腹腔洗浄液 培養結果：胃手術 $13 / 24(54.2 \%)$ ，大腸手術 $24 / 41$ (58. $5 \%)$, 計37/65(56.9\%)にも及ぶ細菌検出率がみられ創保 護が重要. 検出細菌は冒手術ではグラム陽性球菌が多く, 大腸手術では Bacteroides, Enterococcus, E.coliなど の腸内細菌が主体. (3)創感染の改善：諸工夫により創感 染率は胃手術0/24(0\%), 大腸手術 $3 / 41(7.3 \%)$, 計3/ $65(4.6 \%)$ と半減したが,さらなる改善が望ましい. 感染 創の検出細菌は腸内細菌の混合感染が主体。
0-648 Toxic Shock Syndrome $の 1$ 例

平鹿総合病院外科

阿部立也, 平山 克, 中島芳道, 斉滕 研, 寺島秀夫, 島田友幸, 西山宗一郎

Toxic Shock Syndrome（TSS）は黄色ブドウ球菌の増 殖に伴い生体内に産生された enterotoxin により発症す る病態で, 発熱, 発疹をきたし急激に血圧低下, 多缄器 障害をきたす予後不良な症候群であり，本症候群を年頭 に招き早期に診断することが予後の改善に有用と思われ るので報告する．症例は34歳の生来健康な女性で，39.8 度の高熱と悪寒を首訴に当院を受診したが，著明な掻㾕 感を伴う紅斑を全身に認めた。 2 日前加ら感染性痔核の 嵌頓を認め，また生理中でもありタンポンを腔内に㧴入 していた，感染性侍核と診断し，入院の上抗菌剤による 治療を開始した。初診時の血液検查所見では軽度の肝機 能障害と換気障珸を認めるのみであったが，翌日には DIC, ショックをきたすに至り，ステロイドゃ䍇白分解醉 素阻害剤の大量投与を施行したところ，治療は有効であ り，12病日には皮膚落屑が出現し救命しえた。会陰部粘 液培養では黄色ブドウ球菌が検出されたが血液培養では 検出されなかった．診断基準のうち6項目に合致してお り，TSS 症候群と診断してよいと思われた。ある種の夕 ンポン使用によりTSSが多発し社会問題となった事例 も報告されて扔り、この症候群を念頭に扔くことが重要 と考えら就た。

\section{O-649術後に多彩な合併症を発症した腸腰筋膿 瘍の1例 \\ 新行橋病院外科 ${ }^{21}$, 新行橋病院内科2), 福岡和白病院心墭 外科 ${ }^{3 !}$ \\ 石井祥裕 ${ }^{1)}$, 正久康彦 ${ }^{1\}}$, 平野誠太郎 ${ }^{11}$, 岡部勇人 ${ }^{11}$, 鶴崎值邦 ${ }^{1)}$, 田中慎一2)，小迫幸男 ${ }^{3)}$}

【症例】71歳, 男性, 左腰痛を主訴に平成10年9月1日入 院. 発熱，意識障害を伴い炎症反応も高值のため敗血症 が疑われた。第4病日，腹部 CTにて左腸腰筋膿演および 脾腫瘤と診断し緊急に膿愊搔爬術を施行，膿と血液培養 よりMSSA が検出された. 発症2週閒前に腰痛症に対し 近医で局注治療を受けており，医原性感染が疑われた。 術後もSIRS が遷延するため脾臓も䐬瘍を疑い第 9 病日 摘脾施行, 病理骖断は菌塊塞栓による脾梗塞であり重症 の敗血症が示唆された。第11病日, 胃 Dieulafoy 潰瘍加 らの噴出性出血があり，内視鏡的止血術を施行した。そ の後肺炎, ARDS, 心不全を発症し, 人工呼吸管理, 腹卧 位管理法, $\mathrm{CHDF}$ 等の治療によりょうゃく全身状態は改 善した。術後3カ月, 経過中の心不全に対し冠動脈造影を 行ったところ LMT 75\%, LAD 90\%の狭窄を認め, Off -pomp CABG を施行した.また同じ頃下血が出現, S 状 結腸に炎症性狭窄を認め, 術後7 7 月 $\mathrm{S}$ 状結腸切除術を 施行, 術後8力月で退院となった。【結語】現在ではまれ な感染症となった腸腰筋膿㴼の術後に多彩な合件症を発 症し，計4回の手術等により軽快した 1 例を報告した。 
O-650

後腹膜脤煬に併発した左総腸骨仮性動脈

溜の一手術例

東松山市立市民病院外科 ${ }^{11}$ ，日本大学第二外科 ${ }^{2}$

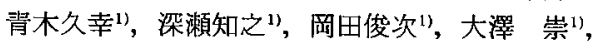
新野成隆")

〔症例〕70歳女性. 平成11年4月上旬より発熱，左側腹部 痛出現し,4月15日腹部 CT 検㚗にて左腸腰䇨唚瘍の診断 で入院。既往歴は，20歳時原疾患不明であるが左腎摘術 施行．その後数回左腸腰筋膿場にて抗生剤治療を受けて いた。 入院時腹部所見で, 左側腹部に自発痛及び腫脹が みられ，左下腹部に圧痛を認めた。検查所見で忙炎症反 応と高度の督血を認めた。腹部 CT, MRI 検査にて左腸 腰筋前面に膿湯と腫瘤椂病変を認めた。 4 月 23 日, 左後腹 膜膿湯腔にドレーン挿入し造影したところ，直腸 S 状部 に瘦孔形成を諗めた。ドレナージにより炎症所見は改善 したが,4月26日より膿瘍腔ドレーンから間欠的に拍動性 の出血が続き，ショックに陥り5月1日緊急手術となった。 〔手術所見〕左総腸骨動脈直上に直腸と瘾着した約 5 ・ の仮性動脈瘤と広範囲の膿瘍腔を認め, 仮性動脈瘤を含 め左総腸骨動脈を結禁切離し，左右大腿動脈人工血管バ イパス，灀孔部の直腸 S 状部切除， S 状結腸人工肛門造 設，膿場ドレナージ術を施行した。術後経過は良好で左 下肢の血行障害もなく，後腹膜膿瘍も柽快した。【結語〕 極めて稀な後腹膜膿湯に続発した感染性動脈瘤の手術例 を経験したので報告する。

\section{O-651 A 群溶血性連鎖球菌による壊死性筋膜炎 \\ の 4 症例 \\ 国立岡山病院外科 \\ 小谷恭弘, 野村修一, 河合俊典, 清水敏成, 最相晋輔, 東 良平}

A 群溶連菌感染症は溶連菌の菌体外毒素により発症し, 壤死性筋膜炎などの軟部組織の壊死病变を伴い, 急速に 多藏器不全を合併する予後不良な疾想として知られてい る.わ机わ机は A 群溶連菌による壊死性筋膜炎の 4 症例 を経験した。うち 2 例は Toxic Shock-Like Syndrome (TSLS) と思われた. TSLSのうち 1 例はショック状態 にて来院し，直ちに抗生物質投与，抗ショック療法を行 ったが, 来院 17 時間後に死亡した。もう1例は来院時 に, 発熱, 下肢の発赤腫脹, 消化器症状を認めていたが, 翌日急激に血圧低下からショック状態に陥った。しかし 本疾患を疑い，培養にて A 群溶連菌を検出し，抗生物質 投与，抗ショック療法などで軽快した。他の 2 例は，抗 生物質投与，切開，皮刑移植にて軽快した。本疾患は常 にその可能性を考え, 培養にて A 群溶連菌を検出し, 未 た臨床症状も合わせ診断に至り，早期に抗生物質投与な ど治療を開始することが重要で，それが予後を大きく左 右する.

\section{0-652}

殿部から仙骨前面，会陰部に生じたガス

\section{壊㾴の 1 例}

安江病院外科

若原正幸, 安江幸洋, 安江紀裕, 安江充里, 須原貴志

【はじめに】ガス壊瘨は，速やかに適切な治療を行わな ければ，重篤で予後不良な疾患である．今回我々は，栯 尿病を基礎疾患に持ち殿部白㿍症が原因と考えられた殿 部から仙骨前面，会陰部にまで及んだ非クロストリジウ ム性ガス壊瘨を経験し救命し得たので文献的考察を加え 報告する。【症例】 51 歳の男性で，熱発と殿部痛を主訴 に来院し切開を加えたが，翌日には会陰部にまで急激に 握雪感を伴う腫張をきたし，皮涌の壊死自瀢と悪臭を伴 う膿汁の排泄を認めた。 X線, CT 検查にて仙骨前面にま で広範囲にガス像を認めたため，直ちに壊死組織を切除 し開放創としてドレナージ術を施行し，術後オキシドー ル洗浄を続け良好な結果を得た。また来院時，低アルブ ミン血症とコントロール不良な糖尿病があり，䈣密な血 糖コントロールを施した.【考察】起炎菌は大腸菌とバク テロイデスであり，好気性菌と嫌気性菌閒の synergistic action を糖尿病が助長したと考えられた 1 例であった。

\author{
0-653 free air 及び門脈がス血症を呈した子宮 \\ 膿腫穿孔による沉発性腹膜炎の 1 例 \\ 弥栄町国民健康保険病院外科 \\ 高垣敬一, 小山 剛, 高㙇 聡, 山本 篤
}

症例は 83 歳, 女性. 腹痛と嘔吐を主訴に当院受診. 腹 部単純写真及び腹部 CT 上腸管の拡張と腹水を認め, 腸 閉塞の䛦断にて緊急入院となった.翌日全身状態が悪化, 再度腹部 CT を施行したところ, 肝内に樹枝状のガス像 を呈す門脈ガス血症ならびに腹腔内に free air 認め た. 消化管穿孔による汎発性腹膜炎との診断にて同日緊 急手術を施行した。開腹所見では，腹腔内に多量の膿性 腹水を認め, 腸管及び腸間膜は暗赤色に変色していたが, 穿孔は認めなかった，子宮は手拳大に腫大しており，底 部後壁に約 $5 \mathrm{~mm}$ 大の穿孔を認め, 同部より膿汁の流出 を認め子宮膿腫穿孔による汎発性腹膜炎と診断した。子 宮全摘術, 両側付属器摘出術および腹腔ドレナージ術を 施行した。病理組織㭘查にて子宮穿孔部に虚血性変化認 めるも悪性所見を認めなかった。術後経過は不良で敗血 症・DIC を呈し, 術後11日目に死亡した。子宮膿腫穿孔 によるfree air を呈する汎発性腹膜炎は非常に稀であ り，本例ではさらに腸管の虚血性変化による門脈ガス血 症を呈していた。 上記症例につき若干の文献的考察を加 え報告する。 
る肺静脈気管支瘦を形成した1例

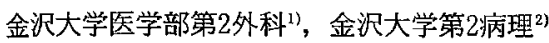

佐々木省三”, 二宮 致"1, 橋本哲夫"1, 谷卓"1,

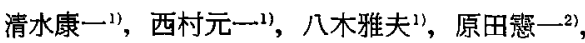
中沼安二21, 三輪晃一1)

食道癌術後に肺アスペルギルス膿湯による肺静脈気管支 瘦を形成した稀な1例を経験したので報告する.症例は68 才，男性. Ut-Mt，T4(左主気管支)，N1，M0，の食道癌に 対し化学放射線療法を行った。主病巣, リンパ節共に縮 小したものの癌巣が残存したため,1998年10月6日に左開 胸開腹食道亜全摘, 3領域リンパ郭清, 全胃管胸骨後経路 挙上頸部吻合及び気管切開術を行った。術後，低酸素血 症，心不全等を経験したがいずれも軽快した。しかし， 術後第25病日に突然気管切開部よりの喀血を認めた。気 管支鏡を行うも出血源は不明であった. 術後第30病日に 再び気切孔よりの大量喀血を認め死亡した．剖検にて組 織学的に気管支右中葉レベルで，肺静脈と気管支との㽷 孔形成を認め, 同部にアスペルギルスの繁殖像が見られ た. 本症例は, 微小なアスペルギルス膿助により肺静脈 気、管支㾇を形成し，気道内出血により窒息死したと考え られた，アスペルギルス感染の原因としては, 術前の化 学放射線療法, 手術侵襲による免疫機能の低下が関与し ていると推測された。

\author{
0-655 胸壁の皮層病変で発症した粟粒結核の1 \\ 剖検例 \\ 盛岡医療生協川久保病院外科 \\ 小野寺健一
}

【はじめに】胸壁の皮豦病変で発症した粟粒結核のI剖 検例を経験した。急速に進展した胸壁の病変を中心に報 告する.【症例】73歳，女。19歳に肺結核。慢性関節リウ マチのため72歳よりステロイド剂服用. 胸部帯状疱疹と して10日前より近医の診療を受けていたが, 局所病変が 拡大し全身状態が悪化してきたので,1999年3月当科に紹 介入院となった．左側胸壁に䳕卵大の皮鹰壊死を認め, その周辺は発赤し自発痛を訴えた。黄色無臭でどろどろ とした渗出夜が流出し，一般細菌は検出されなかった。 表在リンパ節は触知せず，発熱，食欲不振抢よび全身浮 腫を認めた。一種の蜂哃織炎と考え治蹽を行うも，加え って増悪した。皮涌病変は急速に拡大し大きく深い皮層 蛽場となり，乳腺の後面や腋窩，そして広背笳や前鋸筋 の筋膜筋腹にまで広範に及んだ。その後肺炎を併発し入 院42日で死亡した。剖娭により，胸壁病单の皮咸や筋， さらに肺や骨髄など全身臓器に結核病巣を諗め, 粟粒結 核と診断された。院8日目の皮虔生検像では肉芽組織が 軽微なため，生前診断は困難であったが，再検討により 生検時皮虐内に結核菌が証明された。【考察】今回の発生 機序は内因性再燃と考えた。適切な診断のためには，一 定の治療に反応しない感染症では, 結核も強く疑うこと が重要である。

\section{0-656 腹腔内結核症 5 切除例の臨床的検討 平塚市民病院外科}

高林 司，金井歳雄，中川基人，川野幸夫，関 みな子， 向山小百合，吉武明弘，鳥海史樹，宮沢直人

結核は再興感染症として最近再び注目を集めているが肺 外結核症の診断は容易ではない.今回我々は，最近6年間 に当科で手術を施行した腹腔内結核症の5例について臨 床的に検討した。患者の年齢は28-80歳, 5例すべて男性 であった．全例明らかな肺，肺外結核症の既往はなく， 入院時の胸部X線でも結核性病変を疑う所見はなかっ た. 症状発現から入院までの期間は3日から 4 年であっ た. 病変の部位は肝十二指腸間膜リンパ節，回盲部腸間 膜りンパ節，回腸，胆覆，S状結腸であった。回盲部腸 間膜リンパ節，回腸の症例は，各々急性虫垂炎，絞扼性 イレウスが疑われ緊急手術が施行された。また，肝十二 指腸間膜リンパ節, 胆茲, S 状結腸の症例は悪性腫瘍の 疑いで手術が施行された。術前に結核と診断された症例 は無く，術中に採取した胆汁の培養で結核菌が検出され た胆恋結核の 1 例を除き，他の 4 例はすべて切除材料の 病理組織学的検索により診断された。全例術後に行った 喀痰，胃液の結核菌培養は陰性であり，外来で抗結核治 療を施行され結核症の再発なく生存している. 腹腔内結 核症の診断は難しく，時に悪性腫㵿との鑑別が必要とな る。確定診断がつかない病変では常に結核症を念頭にお く必要がある。

\section{0-657術後沈下性肺炎に対する腹臥位理学療法 の経験 松下記念病院外科 \\ 田中宏樹, 中島 晋, 菅沼 泰, 山口正秀, 岡野晋治, 北井祥三, 中川 登, 上野満久, 竹田 靖, 山根哲郎, 安川林良}

【目的】脳梗塞後の四肢運動障害と嶼下困難を持った術 後の難治性の肺炎患者に対して腹卧位理学療法を行い, 効果を上げたので報告する.【症例】症例は73歳の男性 で脳梗塞にて入院中腸閉塞症状出現し精㚗にてS 状結腸 癌認め, ハルトマン手術施行した. 術後から両側肺炎と なり, 術後 5 日目に気管切開した. 通常の理学療法, 気 管支ファイバーでの排痰などで呼吸不全を離脱したが声 带菱縮による唾液たれ込みがあり，沈下性肺炎がそれ以 上軽減しなかった。そこで 1 日 1 時間やや左右に傾けた 半腹臥位とし集中的にタッピングを行った．約 Iヶ月後 のCTで活とんど肺炎像は消失した，その後も腹卧位を 続けていたところ一気に気管に集中した喀痰による窒息 症状を来し, 回復したがその後腹卧位は中止した，通常 の理学療法のみ続けているが 3 ヶ後わずかに沈下性肺 炎像の増加を認めた。【結語】腹臥位理学療法は術後の難 治性の沈下性肺炎に有用であったが危険もあり常に呼吸 を確保できる状態ですべきである。 


\section{O-658} 消化器癌に対する免疫化学療法の現状と

\section{展望}

山口大学医学部第 2 外科

吉野茂文, 俗 彰一, 山本光太郎, 安部俊弘, 岡 正朗

【目的】当科では進行·再発消化器癌に対して, low dose

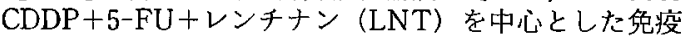
化学療法を施行しており, 本療法の現状につき検討した. 【方法拈よび結果】1. 治撩前後に抢けるQOL の評価を QOL 調査票を使用して行うと，LNT 併用群に比べ FP 単独群では QOLが低下しており，特に身体状況を問う 質問（食欲，嘔気など）においてその低下が顕著であっ た. 2 .細胞内サイトカインの解析により治療前後の Th1/2バランスの推移を見ると，LNT 併用群では Th2 の誘導が抑制されていたが，FP単独群ではTh2優位と なっていた，3．LNT 併用群は FP 単独群に比べ予後良 好であった. 特に, CR 症例は LNT 併用群のみに認めら 九 CR 症例の予後は2年以上と良好であった。 4. LNT 併 用群のなかでも LNT 投与により, 強くTh1優位となる 症例が予後良好であった。【考察】消化器癌患者ではもと もとQOL が損なわれていることが多く化学療法を施行 するにあたってもさらなるQOL の低下㥛力避けなけ ればならない. low dose と言えども FP 療法においては QOL の低下が認められたが，LNTを併用することでこ れを防止できることが確認された. LNT 併用により Th2細胞の誘導が报制され，Th1偭位となることが QOL を維持できる一つの要因になっているものと推察され た。

\footnotetext{
O-659 胃・大腸癌患者に扔ける IL-12の産生能 と反応性の検討一特に IL-12によるIFN $\gamma$, IL-10の産生 について一

日本大学医学部第一外科

柴田昌彦, 朴 英智, 加納久雄, 大原守貴, 根津 健, 竹川本夫, 藤崎 滋, 福澤正洋
}

IL-12はTh1細胞を誘遒し癌の免疫治療には重要であ る。今回, 癌患者における末梢血単核球 (PBMC) の IL -12産生能と IL-12の添加による IFN $\gamma, \mathrm{IL}-100$ 産生動 態について検討した，IL-12の産生は152例を対象に検討 した. PBMC を刺激し培養上清中の IL-12の漂度を測定 した. IL-12の反応能は, PBMCにIL-12を添加し IFN $y$ とIL-10の産生を測定した。また，健常人 8 人，癌患者 10 例を対象に IL-12の添加24時閒後の両者の産生を測定し た. IL-12の産生能は進行に伴い有意に低下した. IL-12 の添加によるIFN $\gamma$, IL-10の産生はともに4時間後には 認められ，IL-12の濃度依存性に IFN $\gamma$ は24時間, IL-10 は30時間後に最高值を示した.24時問後の両者の産生は, IFN $\gamma$ が健常人 $8.03+1.25$, 癌患者 $9.29+3.03 \mathrm{IU} / \mathrm{ml}$ 差がなく, IL-10は健常人 $21.93+4.18$, 癌患者 $47.08+7$. $78 \mathrm{pg} / \mathrm{ml}$ で癌患者で高かった。このように, 癌患者では IL-12の産生は低下し, IL-12添加によるIFN $\gamma$ 産生は健 常人と同等に保たれていたにもかかわらず，この feedback として考えられるIL-10は癌患者で有意に上昇し ていた. 即ち, IL-12の免疫治療にはIL-10などの紐胞性 免疫の抑制機構に对する治蹽が重要と考えられた。

\author{
0-660固形癌に対する癌兔疫療法の展望 \\ 久留米大学外科 - 免疫 ${ }^{11}$, 同兔疫学 ${ }^{21}$ \\ 唐 宇飛 ${ }^{13}$, 山名秀明 ${ }^{21}$, 末吉 晋1), 田中寿明 ${ }^{11}$, \\ 崒 孝志 ${ }^{12}$, 笹富輝男 ${ }^{1)}$, 宮城佳昭 ${ }^{1)}$, 藤田博正 ${ }^{1)}$, 白水和 \\ 雄了
}

固形癌に対し, 癌ワクチン療法の開発を目指して, HLA -A24拘啝性のSART1等ペプチドによる第I相臨床試驗 を進行食道癌，大腸癌等に対して実施中である。その適 応外症例の細胞免疫療法も実行している. その中間結果 を報告し, 癌免疫療法の展望を検討する.SART1, Cyp B と SART3ペプチドワクチンを初回投与量は $0.3 \mathrm{mg} /$ body に設定し, その後は $1.0 \mathrm{mg} /$ body と $3.0 \mathrm{mg} /$ body $の$ 計 3 段階とし, 各コホートの症例数は 3〜4例である. 現在, SART1と SART3は, $1.0 \mathrm{mg} /$ body の試験を, Cyp B は3.0mg/body を続行中である.今まで有害事象は, 注 入部局所の発赤・腫脹, 痛みをみとめ, 投与前皮内反応 試験で, Cyp B(KFHRVIKD)に対して3例中3例が，また SART3 (AYIDFEMKI)に対して 5 例中 3 例がI型ア レルギー陽性であった.ペプチドによる HLA class I 拘 束性癌特異的 CTL の誘導もしくは增強が11例中10例に 認められた.ペプチド投与によりCTL随伴効果が見ら れ，症例毎に CTL 前駆細胞数および反応するぺプチド が異なることが判明した.また，進行食道癌に自己 CTL を局所投与した症例も良好な臨床効果が認められた。 以 上より固形癌のワクチン療法は生体癌免疫反応を高める ことが示唆された。また，自己活性化 CTLにより固形癌 を退緶させることは可能である。

0-661 Current status of cancer therapy using autologous lymphocytes and future perspactives 広島大学原医研腫湯外科

山口佳之, 大田耕司, 清水克彦, 南 一仁, 沢村明広, 峠 哲哉

自己リンパ球を用いた癌治療の現状と新展開再発癌に対 し活性化自己リンパ球 (LAK, TIL, CTL) 移入療を施行 した. 臨床成績を総括し新展開を考察する。過去12年間 の135例中評価可能102の主な対象は消化器癌で, 肝·肺・ 骨・局所結節77例, 例癌性体腔液46例で, LAK49法例, TIL41例, CTL12例. LAK 細胞は400U/ml, TIL および $\mathrm{CTL}$ は $80 \mathrm{U} / \mathrm{ml}$ の IL-2で培養し, 抗原刺激は自己また は同種腫漡紏胞, CEA, Muc-1, SART-1 (久留米大学 伊東先生より供与) ペプチドをパルスした dendritic cell を用いた，1回移入細胞数は平均 $2.4 \times 1009 て ゙$, 有害事象は 発熱 $7 \%$, 頭痛 $1 \%$, 食指不振 $1 \%$. 臓器再発では CR+PR 7 病巣 (9\%)で腫陽縮小効果は低いが, NC38病巣 (49\%), 自覚症状の改善38例 $(52 \%)$ で，1年以上継続施行が7例あ る. 癌性体腔液では著効十有効 36 例 $(78 \%)$ で QOL の改 善が著しい. ペプチドの応用では HLA-A2, A24症例に 対し癌特異的リンパ球の誘導が可能で,7例に臨床応用施 行中である.活性化自己リンパ球移入療法は癌性体腔液 に有効であり,QOL 改善に意義深く外来での長期投与の 貢献もある.ペプチドの応用で質高いリンパ球療法が可 能となった。 
0-662 大腸癌に対する IL-10の作用機序に関す る兔疫学的検討

東京医科大学外科学第三講座

三枝主弦, 坂本啓彰, 梅津清明, 李 正植, 佐藤 晋, 加藤孝一郎, 青木達哉, 小柳泰久

(目的) IL-10はサイトカイン産生を抑制する因子とし て同定されて以来，大腸癌進展の促進因子の一つとして 想定されてきた.しかし，最近の報告では IL-10は生体の 防御機転や免疫能の賦活化に関与することも示されてい る、本研究は大腸癌におけるIL-10の役割を明らかにす る目的で行った。(方法)大腸癌組織ならびに大腸癌細胞 株を用い兔疫学的に検討を行った。(結果)大腸癌組織を 用いた免疫組織学的検討では，IL-100発現は比較的分 化度の高い腺癌で検出され，他の組織系では明らかな発 現を認めなかった．更に大腸癌由来の腺上皮絊胞株 (HT29,colo320DM，colo201）を用い榆討したところ偘 位に IL-10の発現を検出した。腫湯細胞加ら産生される IL-10のリンパ球に与える影響を検討した結果では，IL10により優位な傷害活性の誘導を認めた。更に，ヒトリ コンビナイト IL-10を in vitroでヒト末梢血 T細胞に 添加することによる Fas Ligand(FasL) 発現が誘導され た. (総括) 大腸癌の腺上皮細胞から産生される IL-10は， 癌練胞周囲に浸潤しているリンパ球に対して作用するこ とにより FasL 分子を誘導させ，Fas/FasL システムに より癌細胞を偤害することで，生体に対し防御的に働い ている可能性が示唆された。

0-663 手術侵媱時の単核球でのサイトカイン産 生と白血球数の変動に及汇す性差及び加龄の影響 防衛医科大学校第一外科

松本 疜, 小野 聡, 青笹季文, 辻本広紀, 上野 力, 間嶋 崇, 市倉 隆, 望月英隆

各種侵襲に対する生体反応には個体差があるが，今回 我々は年龄や性差による生体反応の差について，末梢血 単核球でのサイトカイン反応と末梢血白血球数とに着目 し検討した。【対象と方法】胃切除術を施行した胃癌患者 13名（男性10名，女性3名）を対象に，術前(pre)，第 1 病日 (post)に末梢血を採血し，白血球数を測定するとと もに, 単核球を分離 $(1 \times 106$ 個) 後 LPS で刺激 ( $18 \mathrm{hr})$, 培 養上清中の TNF-alpha 濃度を測定比較した.【結果】1, TNF 濃度は男性では術後有意に上昇したのに対し, 女 性では逆に低下した，2，70歳以上の高齢者では術前に 比べ術後 TNF 濃度の上昇傾向を認めた. 3 , 術前 TNF 濃度に対する鿉後の比 (post/pre TNF) は加歯に伴い増 加㑯向を認めたが, 白血球数の比 (post/pre WBC) は加 噛に伴い減少した。【結語】1，男性と女性では侵襲に対 する単核球での TNF 産生能は明らかに異なっていた。 2, 手術侵就時の生体反応における加龄の影響として末 梢血単核球のサイトカイン産生能は増加, 白血球数は減 少傾向を示した.
0-664 CEA 特異的能動免疫療法により血清 CEA 値と抗腫鹪効果に解離を認めた肺癌骨転移の一例 京都付立医科大学消化器外科

清水啓二, 上田祐二, 伊藤 剛, 岡本和真, 白数積雄, 阪倉長平，大辻英吾，北村和也，系井啓純，谷口弘毅， 園山輝久，萩原明於，山岸久一

肺癌骨転移に対し，癌胎児性抗原 (CEA) 由来ペプタイド と末松血単球由来樹状細胞(DC)を用いた特異能動免疫 療法 (癌ワクチン療法) を施行し，血清 CEA は顕著に低 下したものの，腫場は增大し死亡した症例を経験したの で報告する.【症例】52歳女性. 高 CEA 血症 $(66.9 \mathrm{ng} / \mathrm{ml})$ の精査で肺腺癌の診断を得, 平成7年12月左肺下葉切除術 を施行。その後2度綐隔・頝部リンパ節郭清を施行. 外科 的切除の度に CEA 值は一旦低下するが再び上昇を繰り 返した.9年11月仙骨転移再発に対し化学放射線療法を施 行するも CEA 值は急上昇し, 10年12月 CEA 特異的能動 免疫療法を開始した。【治療・経過】末枌血単球からDC を誘導し, CEA 由来 CTL誘導性ぺプタイドをパルスし た後に癌ワクチンとして2週間毎に計22回皮内投与した. 治潦開始時に394ng $/ \mathrm{ml}$ あった CEA 值は $42 \mathrm{ng} / \mathrm{ml}$ にま で低下したが，仙骨転移巣は增大．脳転移も出現し，平 成12年 1 月に死亡した。【考察】血清 CEA と抗腫湯効果 に解離が見られた。癌の免疫学的逃避機構により, CEA 陰性腫瘍の増殖を来した可能性があり，単一の分子標的 を想定した癌特異的免疫療法の限界が示唆された症例で あった。

0-665 鼠径へルニアのメッシュプラグ法再発に 対する脊椎麻西杂下 Preperitoneal approach 法 名古屋第一赤十字病院外科

竹内英司, 小林陽一郎, 宮田完志, 加藤万事, 米山文彦, 西尾秀樹, 池山 隆, 渡邊真哉, 花井雅志, 松原秀雄, 新美清章，落合恵子，河合清貴，鉿木和志，藤井正隆

当院では1995年から鼠径ヘルニアに対して353例にメッ シュプラグ法を施行して抒り，そのうち3例 $(0.8 \%)$ に再 発を諗めた。うち2例に対して脊椎麻酔下 Preperitoneal approach を施行した. 脊椎麻酔下に, 下腹部正中切開を おく．腹膜前腔から鼠径部䘚側に到達する。前回のプラ グに腹膜が強固に瘾着しており，これを剥離する，下腹 壁動静脈を指標として再発形式が外もしくは内鼠径へル ニアであることを診断する。プラグはそのままとし，へ ルニア挛を腹腔側に引き出して、下腹壁動静脈の裏を通 してマーレックスメッシュを内外毀径へルニアおよび大 腿へルニアの発生部位を覆うように固定する．止血を確 認したのち J-Vac ドレーンを腹膜前腔に挿入し閉創し 手術を終了する。本法の利点は，同じ手術経路を通らな いことから，瘾着による影響が少ないこと，また腹腔鏡 下手術と異なり全身麻酔が必要でないこと，さらに本法 は腹膜外経路のため，開腹による合併症はほとんどない ため推奨されるべき手術方法と考えられた。 
O-666

成人ヘルニア梆準術式と術後 QOL にお

ける従来法との比較

岐阜赤十字病院外科

宮内忠雅, 安永 党, 片桐義文, 味元宏道, 鬼束惇義

当院ではへルニア根治術の標準術式として1996年6月 より mesh plug(MP)を, 1999年3月より PROLENE Hernia System (PHS)を用いた tension-free hernioplastyを行っている.今回, 1994年1月より2000年3月の 間に行った成人へルニア手術症例の術後QOLについて 検討した。 方法：従来より行われている手術法(A 群78 例) と MP 法(B 群67例), PHS 法(C 群25例) につき，手 術時間, 術後l週目の疼痛・ひきつれ感, 術後在院日数に つき検討した。結果：局所麻酔下手術または下腹部手術 既往歴のある例は PHS 法が困難であったため MP 法を 行った。手術時間はC群が有意に長かった。術後疼痛・ ひきつれ感, 術後在院日数は $B, C$ 群が有意に短く，また $\mathrm{B}, \mathrm{C}$ 群間に有意差は認めなかった，B群の3例に再発を 認めたが, onlay patch を全周性に逢着してからの再発 は認めていない. 考察：C群は underlay patch 挿入のた め手術時間が長いが，術中術後の QOLには影響しない と考えられた。再発については長期観察が必要であるが, 術後 QOL の点では MP 法, PHS 法は成人へルニアの標 準術式として有用なものであると考えられた。

\section{0-667 PHSを用いた成人鼠径ヘルニア手術 日本大学医学部第 3 外科} 宋 圭男, 佐藤博信, 村山 公, 山形基夫, 岩井重富

【対象と方法】成人鼠径へルニアに対し, 当教室では1998 年11月より PHS (PROLENE * Hernia System)を用 いた Anterior approach 手術を導入し，国径へルニア及 び大腿ヘルニア66例，80病変を修復した。本術式の適応 外は1)奼娠の可能性の有る女性 2) 血液凝固系の異常 4) 嵌頓などの緊急手術例である.手術の実際は 1) 外鼠径輪 より皮虞割線に沿う切開 2)へルニア霆の高位・二重貫通 結禁 3)腹膜前筋膜浅葉の切開と preperitoneal space の 豩離 4) PHS の挿入と under lay mesh の展開（最近では 『精巣動静脈・精管の腹壁化 parietalization』による mesh の充分な展開) 5) on lay mesh の縫着である.【成 績】付加手術を行った症例を除く75病変の平均手術時間 は71.3土20.7分であり，同時期に施行したPlug mesh 法 による修復術 13 症例の平均手術時間 $61.5 \pm 18.2$ 分と比べ 有意の差は無かった。術後在院日数は平均 $5.1 \pm 2.1$ 日で あった。また2000年3月より Derma Bond *による術創 の被覆により, 術後在院日数はさらに $3.1 \pm 1.1$ 日と短縮 した。【結語】PHSによるへルニア修復術は, preperitoneal space の豩離が腹腔鏡下手術での豩離層とほぼ 同一であると考えると理解し易い. 再発症例は未だ経験 なく, 従来手術と比べ遜色ない成績が期待でき, 術後疼 痛も少なく入院期間の短縮にも奇与する.
0-668成人鼠径ヘルニアに対する標準手術（へ ルニアシステム安用いた onlay and underlay patch 法) 福岡大学医学部第二外科

酒井憲見，山下裕一，前川隆文，白日高歩

成人鼠径へルニアに対する手術は tension free 手術法の 出現によって大愊に変化してきた。特に mesh plug が開 発されてからは多くの施設で mesh plug 法が行われ，術 後愁訴の軽減, 入院期間の短縮および再発率の減少など が報告されている。 また onlay and underlay patch 法 を簡便に行うへルニアシステムの開発によって, ますま す tension free 手術法が選ばれるようになってきた。当 科においては1995年より mesh plug 法を行ってきたが, 再発症例に扔いて鼠径管後壁の補強が不十分である可能 性が考えられ，現在は闻径管後壁の脆弱を認める症例で はヘルニアシステムを用いた onlay and underlay patch 法を行っている. onlay and underlay patch 法は鼠径部 の解剖に即した Hesselbach三角を含めた後壁補強法で あり, 現在再発は認めていない. 従って, ヘルニアシス テムを用いた onlay and underlay patch法は成人舀徍 ヘルニアに対する標準術式になりうると思われる。

\author{
0-669 当院における鼠径へルニアの治療方針 \\ 筑豊学災病院外科 \\ 福島正之, 井原 司, 児玉孝仁, 田中英二, 別府俊治, \\ 東 隆也, 岡部正之
}

現在㼙径へルニアに対して数種類の手術が行われている が, 個々の症例に応じて, ヘルニアの状態, 㭧者背景, リスクなどを考慮して手術法を選択するのが重要と思わ れる.当院において現在まで（1）Potts 法, Marcy 法 12 例, (2) Tension repair (従来法) 134 例, (3) Mesh plug 法 (MP法) 17 例，（4）鏡視下ヘルニア 44 例, ( 5 ) inlay mesh を使用する腹膜前修復法(APR) 4 例, 施行した. それぞれの手術時間, 平均在院日数, 再発率注（1）（46.5分 8.0日 $0 \%$ （2）(77.7分，13. 0 日 $5.3 \%)(3)(53.1$ 分 9.5 日 $0 \%)(4)(84.9$ 分 9.4日 $2.1 \%$ )（5）(58分 9.4 日 $0 \%$ ）だった。また 術後退院後の合併症, 愁訴についての検討では鼠径部腫 張, 疼痛が従来法に, 違和感が MP 法に多くみられた。 鏡視下ヘルニアでは臯径部腫張，違和感は見られるもの の従来法, MP 法に比し少なかった. 現在当院では視診, 触診, 立位時の超音波検査等でヘルニアの状態を把握し ているが，息者背景，リスクを考慮に入れ，ヘルニア門 の大きいもの (Nyhus III A 型) 再発型 (Nyhus IV 型) 両側, 複合型に対して鏡視下へルニア根治術, 若年者に は異物をできるだけ使用しない方法，その他はMesh plug 法, APR を施行している. 
Parastomal hernia に対し Marlex Mesh を用い, 根治 術を行い良好な結果を得た 2 例を経験したので文献的考 察を加えて報告する。症例 1 85才女性.8年前, 大腸欯 室炎穿孔による沉発性腹膜炎に対し stoma を造設され た. 術後5年より, Parastomal hernia を発症し ileus 症 状をくり返す為手術適応となった. stoma の内側頭尾方 向（ヘルニア門上）に弧状切開を扤き直接縫合閉鎖した 後 mesh をあて, 腹直筋膜と大腸壁に固定した。症例 2 71才男性. 3年前直腸癌に対しマイルズ手術施行. 術後1 年より stoma 外側に hernia 認め洗腸困難, 便秘症状 強く手術適応となった. stoma の外側にヘルニア門直上 に弧状に切開. 直接縫合閉鎖は行わず mesh をおき,内腹 斜筋膜と大腸壁に固定した。 Parastomal hernia の本邦 での発生率は $0.7-1.7 \%$ ありり,多くは保存的に加療され るが ileusなどの原因となるものに対しては手術が行わ れる.しかしヘルニア門の閉鎖のみや stoma 再造設では 再発が多いとの報告もあり，近年 Marlex Meshの有用 性が報告されている。我々の症例ではCTにてヘルニア 門の位置を把握, 直上周囲に約 $1 \mathrm{~cm}$ 離して弧状皮简切開 を扔きapproach, Marlex Mesh を用い, 無理な直接縫 合閉鎖を行わないことにより良好な結果を得られたと考 える．今後，症例を重ね更に検討をすすめたい。

\author{
0-671 鼠径ヘルニアに対するメッシュプラグ法 \\ についての検討 \\ 自治医科大学大宮医療センタ一外科 \\ 樋口智江，遠山信幸，甲斐敏弘，住永佳久，小西文雄
}

鼠径ヘルニアに対するメッシュプラグ法は，再発率も低 く，優れた方法とさ狆ている。我々の施設でも1997年以 降メッシュプラグ法を標準術式として行っている. 今回 我々は当院でメッシュプラグ法を施行した鼠径ヘルニア 症例を対象に，再発例を中心に手術法に対し検討を行っ た。対象と方法 1997年1月より2000年4月までに施行し た146例163病変. 平均観察期間1年7ヶ月. 男性133例, 平 均年歯 64.9 歳，女性 13 例，平均年歯5 52.9 歳であった。右 側 40 , 左側 89 , 両側 17 例, 内鼠径へルニア $38 \%$, 外鼠径 ヘルニア $60 \%$, 内十外鼠径へルニア $2 \%$ あ゙あった. 結果 メッシュプラグ法を146例に施行し，そのうち再発は3症 例4病変であった。メッシュプラグ法初回手術時, 3病変 は外鼠径へルニアで，1病変は内鼠径へルニアであった。 いずれも挿入したプラグの内側の恥骨結節奇りからで内 鼠径ヘルニアの形での再発であった。再発までの期間は 術後 1 週間以内 1 病変, 2 力月 2 病変, 7 力月 1 病変と全て 1 年 以内の再発であった。まとめメッシュプラグ法術後再 発防止のために, プラグの大きさの選択, onlay patch の 固定, ヘルニア胙の処理など各施設様々な工夫をしてい るのが現状である。当施設での症例を中心に文献的考察 を加え，再発防止の為の手術法を検討したので報告する。
0-672鼠径へルニアに対する新しい術式 PROLENE Hernia System 法と Mesh plug 法の比較娭 討

岐皁県立岐皁病院外科

河合雅彦, 丹羽隆普, 安四邦彦, 高橋禎雅, 山森積雄, 古市信明, 三沢惠一, 大橋広文

【目的】鼠径へルニアに対する新しいTension-free 術 式である PROLENE Hernia System 法（以下P 法）と Mesh plug 法 (以下 M 法)の比較検討を行った。【方法】 1998年12月〜2000年 1 月までにP法を行った鼠径へル 二ア25例とほほ同時期に行った $\mathrm{M}$ 法の42例について手 術時間 - 術後入院期間 - 術後の鎮痛薬使用状況 - 合併症 再発率を比較検討するとともに入院中・退院後の疼痛・ 突っ張り感・異物感・手術に対する満足度などについて アンケート調查を行った。【結果】手術時間は M 法37.22 分, $\mathrm{P}$ 法45.68分, 術後入院期間は各々 4.38日, 4.76日 と 若干 M 法が優れていた，M法でヘルニアの型の診断の 誤りによると考えられる再発例を 2 例に認めた。アンケ 一ト調查の結果, 疼痛突っ張り感・異物感などは $\mathrm{M}$ 法が 優狆ている傾向がみられた。しかし手術に対する満足度 は P 法が若干優れていた.【総括】手術後の観察期閒が短 く術後早期には $\mathrm{M}$ 法が優れている傾向がみられたが, へ ルニアの型の診断の詰りによると思われる再発例 2 例が みられ，手術手技に若干の馿れを必要とするものの長期 的にはP 法の有用性が示唆された。

0-673 成人鼠径ヘルニアに対する tension-free hernioplasty $の$ 検討

更埴中央病院外科 ${ }^{13}$, 富山医科蒋科大学医学部第 2 外科 ${ }^{21}$ 宗像周二"1，新保雅宏 ${ }^{21}$, 唐木芳昭 ${ }^{12}$, 大西雄太郎 ${ }^{11}$

【目的】97年7月から tension-free hernioplasty33例を経 験したので，従来法と比較検討した。【対象と方法194年 4 月から00年3月までに当院外科で手術を行った成人鼠径 ヘルニアは94例で, 従来法施行群61例と tenson-free hernioplasty（以下 T-F 群と略す）33例を手術時間，術 後在院日数, 歩行までの日数, 術後疼痛などについて比 較検討した.【結果】従来法は初回手術59例63病変, 再発 5例5病変, $\mathrm{T}-\mathrm{F}$ 群は初回手術31例31病変, 再発2例2病変 であった。術式は従来法で iliopubic repair47例, Mc Vay5例，Marcy4例，Bassini1例であった。 T-F 群では prostesisとして onlay patchのみ使用した例が9例， mesh plug18例, Proline hernia system4例, 再発例に はplugのみ2例であった。従来法群と T-F 群間で手術 時間, 歩行までの日数, 術後在院日数を比較すると手術 時間で各々61.4分と54.2分で差はなかったが，術後の歩 行までの日数は2.2日対0.9日，在院日数が9.6日対6.7日 で T-F 群がいずれも短縮し術後疼痛も軽い傾何が見ら 礼た。再発注従来法施行群3例 (4.9\%), T-F 群では現在 まで無加った。【結諭】成人四径ヘルニアの術式として tenson-free hernioplasty 学今後とも実施していきた w. 
0-674 Prolene Hernia System ${ }_{\mathrm{R}}$ 用いた砙径 ヘルニア修復術の検討

中野総合病院外科

朴 成進, 石田孝雄, 小畑 満, 権田 剛, 中村勝運, 有賀智之

【目的】Patch 法, Plug 法双方の利点を併せ持つ Prolene Hernia System ${ }^{\mathrm{R}}$ が最近になって開発され，その 有用性が各所で報告されている。同補強材料を用いたへ ルニア修復術後の疼痛, 違和感, ひきつれ感について従 来法との差を検討するため, アンケート調查を行った。

【方法】1998年12月加ら2000年3月にかけて同補强材料を 用いて修復術を行った内外鼠径へルニア，大腿ヘルニア 計55例, 従来法計50例に対し，術後1ヶ月，3ヶ月，6ヶ月 後の疼痛，違和感，ひきつれ感に関するアンケートを作 成し，郵送した。【結果】補強材料法29例，従来法28例の 有効回答があり，それぞれのスコアに対して MannWhitney のU 検定を行ったところ，1ヶ月後の疼痛，違 和感，ひきつれ感，3ヶ月後のひきつれ感に抒いて2群間 に有意差を認めた。【総括】補強材料を用いた鼠径へルニ ア, 大腿へルニア修復術は, 主として再発へルニアに適 用されてきたが，近年は初回手術時にも使用されるよう になってきた.しかし，その適応，安全性については未 だ議論の余地がある.今回我々は, Prolene Hernia System ${ }^{\mathrm{R}}$ を用いた鼠径へルニア修復術後のアンケート調査 を行ったので，その結果を基に，文献的考察も加え，有 用性，今後の課題について報告する。

\section{O-675腹腔鏡観察による成人ソケイヘルニア修 \\ 復術の検討 \\ 杏林大学医学部第一外科 \\ 茂木瑞弘，下位洋史，中島正暢，森 俊幸，跡見 裕}

目的：成人ソケイヘルニアに対する Mesh plug 法, PHS 法は近年急速に広まってきている。しかし，ヘルニア門 やヘルニア䣬の同定が困難な症例もあり，また嵌頓へル ニアに対する適応も不明確である。今回我々は腹空鏡観 察下にMesh plug 法を使用した成人ソケイヘルニア修 復術を行いその有用性を検討した。方法：2000年3月まで 両側例を含め,成人ソケイヘルニア225例に対して Mesh plug 法を行った。結果：性別は男性176例, 女性31例で, 平均年歯は65.3墄であった。このうち12例に腹腔鏡によ る観察を行った．腹腔鏡観察を行った症例は Mesh plug 法施行後再発例1例, 術後血腫例1例, 術前診断不明例1例, 嵌頓ヘルニア6例，腹腔鏡下胆夜摘出術後の初発例 3 例て 何れの症例においてもへルニアの正確な診断が可能であ り，血腫や，液体貯留の診断も容易であった. Mesh plug 法後の再発例は plug の Migration がその原因と考えら れた。また嵌頓例では逻納した腸管のViability を腹腔 鏡下に確認し引き続き Mesh plug 法を施行した。総括： 診断困難例，嵌頓ヘルニア症例において腹腔鏡で観察し 診断することは有用であると考えられた。
0-676 局所麻酔によるPROLENE HERNIA

SYSTEM を用いた成人䦠径へルニア根治術

大原綜合病院附属大原医療センター外科 ${ }^{1)}$, 福島県立医 科大学外科学第二講座 ${ }^{2}$

安斎圭一1), 関川浩司 ${ }^{2)}$, 八巻俊彦1), 安藤善郎 ${ }^{1)}$, 竹之下諴一2)

近年成人䬑径ヘルニアに対しては tension free hernioplasty が導入され非常に良好な成續が得られるように なった，当科で仙平成10年1月より BARD社の Mesh PerFix Plug 使用し，さらに平成10年12月ょり ETH ICON 社 Prolene Hernia System を使用し, それぞれ25 例・33例に対して手術を施行した。麻醉は主に腰椎麻醉 で行っているが，最近は心疾患・呼吸器疾患を持つ症例 および早期退院を希望する患者に対しては積極的に局所 麻酔にて行っている. 局所麻酔にて手術を行う場合は, Braunの伀達麻酔に準じ，1\%キシロカインを用いて腸 骨鼠径神経・腸骨下腹神経をブロックし，皮切部扔よび 外鼠径輪周囲に浸潤麻酔を行っている。術中にやや疼痛 を訴える例もあるが，そのような場合には適宜麻酔楽を 追加し，手術を遂行している．本方法では術直後より歩 行でき，早期退院が可能であった。本法は Day Surgery を施行する際には有効な方法であり今後益々応用される べき手技であると思われた。

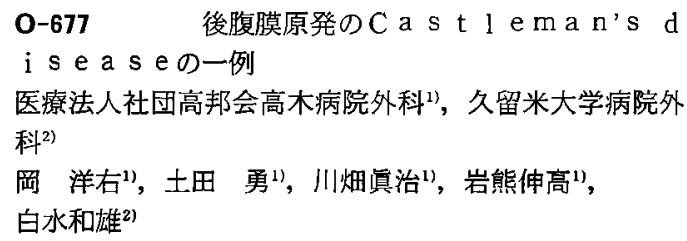

特発性のリンパ增殖性疾患であるCa s t 1 e ma n' s d i s e a s e の好発部位として維隔および頸部と の報告は多い.今回我々は発熱，下腹部痛を主訴とし， 術前にCast 1 e man's d i s e a s e を疑い, 切除し得た後腹膜原発のC a s $\mathrm{l}$ e ma n's d i s e a s e の一例を経験したので, 若干の文献的考察を加 えて報告する。 